\title{
Non-Custodial Sanctions Policy in Renewing the Criminal System in Indonesia (Study of Non-Custodial Sanction Approaches in Draft Law of the Criminal \\ Law)
}

\author{
Rini Fathonah ${ }^{1}$, Sunarto ${ }^{2}$, Mashuril Anwar ${ }^{3}$ \\ \{rinifathonah@gmail.com¹, sunarto@fh.unila.ac.id², mashurilanwar97@gmail.com³ \\ Universitas Lampung, Indonesia ${ }^{123}$
}

\begin{abstract}
Non-custodial sanctions are formulated in the Law Draft on the National Criminal Code (RUU KUHP) with various forms and criteria in terms of their application, as determined in Article 70 of the Criminal Code Bill. The problem in this research is what is the philosophical basis for determining non-custodial sanctions policies in the Criminal Code Bill is? Moreover the study searches for the crime and how the measurement/criteria in determining the appropriate non-custodial sanctions imposed on the perpetrators of criminal acts based on the Criminal Code Bill. This study aims to examine and analyze the philosophical basis for determining non-custodial sanctions policies in the Criminal Code Bill, as well as studying and analyzing criminal acts and measures/criteria in determining the appropriate non-custodial sanctions imposed on perpetrators of criminal acts based on the Criminal Code Bill. This research is a normative study using secondary data obtained from library materials. Results showed, in essence, the philosophical basis for determining non-custodial sanctions policies in Criminal Code Bill respecting and upholding human rights, and creating a balance based on religious, moral values of divinity, humanity, nationality, citizenship, and social justice for all people Indonesia. Furthermore, the imposition of non-custodial sanctions for perpetrators of crime guided by the provisions of Article 71 of the Criminal Code Bill. Based on the results of the study, it is recommended that the Criminal Code Bill immediately passed into law and non-custodial sanctions prioritized by law enforcement in handling criminal cases.
\end{abstract}

Keywords: Policy; non-custodial; punishment

\section{Introduction}

Non-custodial sanctions alternative forms of imprisonment (alternative to prison) which are forms of non-institutional acts in consent. It is an alternative to all types of liberty deprivation that place a person institution/institution or other areas detention/confinement/isolation. Furthermore, in development of non-custodial sanctions alternative imprisonment in the "Criminal Justice Handbook Series", stated that: "noncustodial sentences may also be acceptable if their punitive elements meet the standards of human dignity and the rule of law". The above statement interpreted that in the application of non-custodial sanctions, considers several aspects of respect for human rights, social justice 
and the need for rehabilitation of perpetrators of crime and also considers some legal rules that contain provisions regarding non-custodial sanctions. Furthermore, in the "Handbook of Basic Principles and Promising Practices on Alternatives to Imprisonment", determined several forms of non-custodial sanctions in the "Tokyo Rules", including:

1. Verbal sanctions, such as caution, reprimand, and warning;

2. Conditional discharge;

3. Status of penalties;

4. Economic sanctions and monetary penalties, such as fines and day-fines;

5. Confiscation of an expropriation order;

6. Restitution to the victim or a compensation order;

7. Suspended or deferred sentence;

8. Probation and judicial supervision;

9. A community service order;

10. Referral to an attendance center;

11. House arrest;

12. Any other modes of non-institutional treatment;

13. Some combinations of the measures are listed above.

Based on a survey conducted by the Council of Europe illustrates that there are currently approximately 22 alternatives to criminal deprivation of liberty in Europe. It demonstrates that even the denial of criminal justice is difficult to abolish, but as far as possible, it must be avoided and other alternatives are sought. Furthermore, in the context of renewing criminal law, non-custodial sanctions are also formulated in the Law Draft on the National Criminal Law (RUU KUHP) with various forms and criteria in terms of their application. As stipulated in Article 70 of the Criminal Code Bill, that: with due regard to Article 54 and Article 55 of the Criminal Code Bill relating to the Objectives and Guidelines for Criminal Conduct, imprisonment be imposed for possible, if the following conditions found:

1. the defendant is a child;

2. the defendant is over 75 (seventy) years old;

3. the defendant is committing a crime for the first time;

4. the loss and suffering of the victim is not too significant;

5. the defendant has paid compensation to the victim;

6. the defendant did not realize that the criminal activities carried out would cause a considerable loss;

7. the crime occurred because of powerful incitement from others;

8. Victims of a criminal law encourage or mobilize the occurrence of such crimes;

9. the offence is a result of a situation that is unlikely to be repeated;

10. the defendant's personality and behavior assured that he would not commit any other crime;

11. imprisonment will cause great suffering to the defendant or his family;

12. guidance outside the correctional institution is expected to succeed for the defendant;

13. the conviction of lighter crimes will not reduce the severe nature of the criminal offence committed by the defendant;

14. Crimes occur among families; or

15. Crime due to negligence. 
Based on the description, it seems that it is essential to apply non-custodial sanctions looking at some of the considerations contained in the perpetrator, in a victim and looking the level of loss resulting from crime and impacts the community then application of noncustodial sanctions very likely carried out remedy defendants, victims and public. Is also certainly as an embodiment of restorative justice by carrying out the settlement of cases/criminal acts by involving perpetrators, victims, perpetrators/victims' families to seek a fair solution by emphasizing restoration back to its original state and not retaliation. Based on this description, it becomes relevant and interesting to study the non-custodial sanctions policy in the renewal of the criminal system in Indonesia contained in the Criminal Code Bill.

Based on background description above, the problems in the study are what is the philosophical basis for the determination of non-custodial sanctions policies in the Criminal Code Bill and against criminal offences and how is the size/criteria in determining the appropriate non-custodial sanctions imposed on perpetrators is a crime based on the Criminal Code Bill is? This study aims to examine and analyze the philosophical basis for determining non-custodial sanctions policies in the Criminal Code Bill and reviewing and analyzing criminal acts and measures/criteria in determining the appropriate non-custodial sanctions imposed on perpetrators of criminal acts based on the Criminal Code Bill.

\section{Methods}

This research is a normative study conducted using secondary data obtained from library materials. In connection with research on the application of non-custodial sanctions, there will undoubtedly be a lot of use of books or journals deemed relevant to study the application of sanctions.

\section{Results and Discussion}

Philosophical is the Base for Non-Custodial Sanction Policy Determination in the Criminal Code Bill. Renewal of criminal law is not an easy thing to do. Since the beginning of its development, criminal law has been concerned with human dignity. Criminal law in its growth directed at the protection of human rights. Therefore, the renewal of criminal law does not only concern the substance but also relates to existing values. Restoration criminal law, implies an effort to reform criminal law following the sociophilosophic, sociocultural, illegal policies, and legislation. Indonesia is currently undergoing a renewal of the criminal law, one of which is manifested in the drafting of the Criminal Code Book (the Penal Code Draft).

According to Sudarto, there are 3 (three) reasons for the need to renew the Criminal Code, namely political reasons, sociological reasons, and practical reasons.

1. Political rights, based on the idea that an independent state must have its national laws for the sake of national pride;

2. Sociological reasons, require the existence of laws that reflect the cultural values of a nation;

3. Practical ideas, among others, stem from the fact that usually, the former colonies inherited the law that colonized it with the original language, which many did not understand by the younger generation of the newly independent country. This because usually, the newly independent country wants to make its language as a unitary 
language so that the language of the colonial state only owned by the generation that has colonized.

One substance of the renewal of the national criminal law as outlined in the Draft National Criminal Code is non-custodial sanctions. Non-custodial sanctions are alternative forms of imprisonment which are forms of consents or non-institutional acts or in other words as an alternative to all types of deprivation of liberty that places a person in an institution/institution or other places of detention/confinement/isolation. The emergence of non-custodial sanctions as an alternative to imprisonment expressly set out in the main document of the General Assembly Resolution of the United Nations 45/110 (after this abbreviated to the United Nations) on "United Nations Standard Minimum Rules for Non-Custodial Measures", dated December 14, 1990, known with the term "Tokyo Rules". This draft resolution is the result of the 1990 United Nations Congress on "the Prevention of Crime and the Treatment of Offenders" held in Havana, Cuba on August 27 to September 7, 1990.

Furthermore, the form of non-custodial sanctions as "Alternatives to Imprisonment" is also confirmed in Penal Reform International (after this abbreviated as PRI), which states that: "Alternatives to Imprisonment cover range of sanctions aim to restore the relationship between the offender, the victim and the wider community by taking into consideration the rehabilitative needs of the offender, the protection of society and the interests of the victim. Specific alternative measures include mediation, diversion, community service and administrative and monetary sanctions." (Alternative imprisonment, includes a series of sanctions aimed at improving relations between perpetrators, victims and the broader community by considering the needs of perpetrators, community protection, and the interests of victims.

The above shows that the PRI also wants the application of non-custodial sanctions against perpetrators of criminal acts in various forms as an alternative to imprisonment while still considering aspects of justice both perpetrators, victims and community protection (issues of restorative justice). The PRI also stated "is the prison sentence always a solution?". By looking at the damaging effects of unnecessary use of prisons around the world and making a case for greater use of non-custodial acts. Furthermore, the renewal of the national Penal Code based on various issues, including the point of over-criminalization in criminal acts as a result of criminal law is not selective and limitation, of course, will also have an impact on overcapacity within the prison. The issue of escaped prisoners is partly problems arising from the effect of overcapacity in with a various complex problem. The application of non-custodial sanctions at each stage as an alternative to imprisonment is not solely to resolve or overcome the issue of overcrowding. But more broadly that which is a reflection of fundamental changes in approaching crime, perpetrators, and place in society, as well as a reflection of changes in penitentiary actions from crime and isolation to restorative and reintegration justice from punishment and isolation to restorative justice and reintegration.

This argument is in line with the philosophical foundation of the stipulation of the Criminal Code Bill, namely that efforts to reform criminal law in Indonesia must be based on the national goals to be achieved by the Indonesian people as an independent and sovereign state. The Criminal Code, which is still in effect, is a legal product of the Dutch East Indies government, which needs to be adjusted. A fourth of a paragraph the opening of 1945 Constitution of the Republic of Indonesia must be used a benchmark for the implementation of the renewal. In other words, the restoration of criminal law must be a means to protect the entire Indonesian nation and all of Indonesia's blood spill, promote public welfare, educate the nation's life, and participate in carrying out world order based on independence, lasting peace and social justice. National criminal law material is adapted legal politics, circumstances, 
federal and state life development aimed at respecting and upholding human rights and creating a balance based on religious, moral values of the Almighty God, humanity, nationality, society, and social justice for all people of Indonesia.

Related renewal of criminal law, there are at least two objectives to be achieved by criminal and criminal law, namely inward and outward goals. The purpose of inward is the renewal of criminal law carried out as a means for the protection of society and the welfare of the Indonesian people. Both of these goals serve as a cornerstone (cornerstone) of criminal law and criminal law reform. While the purpose of exiting is to participate in creating world order in connection with the development of international crimes (international crimes), protection of the community (social defense) with law enforcement in criminal and criminal renewal carried out with the aim of:

1. protection of society from anti-social acts that harm and endanger the community. The objective of punishment is to prevent and overcome crime.

2. protection of the city from the dangerous nature of a person, the criminal/criminal punishment in criminal law, aims to improve the perpetrators of crime or try to change and influence their behavior so that they return to the law and become good and useful citizens.

3. protection of the public from the misuse of sanctions or reactions from law enforcers as well as from citizens in general, then criminal objectives are formulated to prevent arbitrary mistreatment or acts.

4. protection of the community from disruption of the balance or harmony of various interests and values resulting from crime, the enforcement of criminal law must be able to resolve conflicts caused by criminal acts, be able to restore balance and bring a sense of peace in society. Community protection in this regard also specifically covers the protection of victims of crime, which after the Second World War came to light. Victims in this case also include victims of "abuse of power", who must obtain compensation and assistance protection.

Based on the philosophical foundation of the RKUHP above, in essence, the formation of a national RKUHP aims to replace the colonial product KUHP (WVS) which is not by the values of Indonesian society. In the colonial Criminal Code, contains provisions regarding non-custodial criminal provisions contained in Article 10 of the Criminal Code, namely criminal fines, criminal cover, revocation of individual rights, seizure of certain goods, and announcements of judicial decisions. However, criminal sanctions in Article 10 of the Criminal Code have not fully accommodated the current problems of Indonesia, especially the criminal aspect. Penalties in the colonial Penal Code tend to be retaliation which is identical to imprisonment. In contrast, the current condition of Indonesia shows that detention raises various problems such as overload Penitentiary Institutions.

Based on the above, the application of non-custodial sanctions at each stage can reflect a restorative justice. As stated by Topo Santoso that: "In the last few years this has been a matter of punishment for perpetrators of crimes which are sometimes very mild but received prison sentences offend the sense of justice of the community. It can be answered by developing restorative justice. If someone is also forced brought into the criminal justice system, then it is better to use several alternatives of non-prison punishment which the level of effectiveness is still always a question up to now ".

Based on the description above, the idea of restorative justice is no longer a concept or discourse, but more than that in the development of restorative justice has been continuously considered as the policy legislation and the justice system. Restorative justice is a process of resolving violations of law committed by bringing victims and perpetrators (suspects) together 
to sit in a meeting to speak together. It was also stated restorative justice offered the best solution in resolving criminal cases, namely by giving priority to the core problems of a crime. The solution that is important to note is to repair damage or losses arising from a crime. Furthermore, in restorative justice, the perpetrators are also allowed to explain clearly about the actions taken in the sense that the perpetrators explain the conditions and cause why the perpetrators committed crimes that cause the victim's loss in the hope that the victim will respond to the explanation. Is at least relevant to the guarantee of legal protection that the application of non-custodial sanctions is based criteria including "the personality, background of the offender and the right of victims".

The above description shows that the importance or urgency of applying non-custodial sanctions in the context of the realization of restorative justice begins with criticisms of imprisonment both in extreme and moderate critique. Excessive criticism which wanted to abolish the prison sentence altogether felt to be impossible to apply. Therefore reasonable criticism (criticism from the perspective of strafmodus, strafmaat, strafsoort as described earlier) which felt appropriate to be considered one of the things that underlie the application of non-custodial sanctions against perpetrators of criminal offences. The urgency of an alternative unlawful revocation of independence (prison) in the context of renewing criminal law occupies a central position in the criminal sanctions system in addition to the illegal dismissal of freedom which turned out to be challenging to abolished. Furthermore, philosophically some things are contradictory that is related to the purpose of prison and the function of prison as stated below:

1. That use of detention first is to guarantee the security of prisoners, and second is to provide opportunities for prisoners to rehabilitate.

2. The nature of the prison function mentioned above often results in the dehumanization of the perpetrators of crimes. It ultimately causes losses for prisoners who are too long in the institution, in the form of the prisoner's inability to continue their lives productively in society.

Based on the description above, there has been a paradigm shift in punishment in Indonesia. Criminal punishment in the colonial penal code (WVS) emphasizes retribution (retributive) against the perpetrators of criminal acts. Whereas discipline in the national RKUHP is oriented restorative justice. Can be seen from the provisions of Article 51 of the RKUHP, that the penalties aimed at:

1. prevent criminal acts by upholding legal norms for the protection and protection of the community;

2. popularize the convicted person by providing guidance and coaching to be a right and useful person;

3. resolve conflicts caused by criminal acts, restore balance and bring security and peace to the community; and

4. foster remorse and free guilt on the convicted person.

Then it is confirmed by the provisions of Article 52 RKUHP that punishment is not intended to demean human dignity. This shift in the paradigm of punishment caused by three main factors, namely the development of human rights, changes in people's views of crime and differences in people's opinions of criminals themselves. The paradigm shift is not only happening in Indonesia; the application of non-custodial sanctions is not only accommodated in many provisions in the favorable law legislative policy in Indonesia as described previously. A comparative study use non-custodial permissions, can be seen from countries including France in Law No. 70-643 dated July 17, 1970, which stipulates a judge imposing a 
prison sentence of 6 months or less, provide the opportunity for a convicted person to serve his sentence outside the prison institution to:

1. Following training courses or other studies (to follow a training course or others studies);

2. Doing work (to pursue an occupation); or

3. Undertake medical care (to undergo medical treatment).

Furthermore, the application of alternative custodial crimes (alternative to custodial sentences) in Greece can be pursued, among others by:

1. Conversion of custodial crime with a fine;

2. Criminal delayed / conditional (suspended sentence);

3. Conditional Release (conditional release);

4. Reduction of imprisonment for doing good work (Goodtime allowance).

Also in Portugal, the criminal intended as an alternative to imprisonment is seen in the provisions governing:

1. Conditional punishment (suspended sentence) and criminal supervision (probation order)

2. Reprimand (reprimand).

3. Limited release (limited release or parole).

4. Do not impose a crime (non-imposing of a penalty).

About non-custodial sanctions, Australia is also a country that is very progressive in terms of the application of these sanctions. In Australia, non-custodial sanctions can be applied to various violations. Especially for some minor violations. Legislative provisions also maximize non-custodial sanctions. Illegal imprisonment is the most severe criminal offence in Australia and generally must be imposed as a last resort. Listed below are several forms of noncustodial sanctions in order ranging from mild to the most severe:

1. Criminal without supervision, including:

a. release, parole, and guarantee;

b. fine.

2. Criminal supervision, including:

a. Community service and trials;

b. Intensive supervision or intensive criminal repairs.

3. Criminal substitutes from prison, including:

a. Conditional postponement / criminal;

b. House arrest and detention at periodic times.

In line with the renewal of criminal law and philosophical considerations in the determination of the policy of non-custodial sanctions, it is clear the urgency of alternative illegal deprivation of independence with the formulation of non-custodial sanctions in the Indonesian RKUHP.

\subsection{Size/Criteria in Determining Non-Custodial Sanctions that are Appropriate/ Appropriate Imposed by Criminal Actors Based on the Criminal Code Bill}

Nowadays, the problem of increasing the use of alternative criminal deprivation of liberty (non-custodial sanction) has become a universal problem, proved by the attention of the United Nations to this problem. Subcommittee 11 of the Sixth United Nations Congress on the Prevention of Crime and the Treatment of Offender in 1980 in Caracas, which discussed the topic of De-institutionalization of corrections which provides the following recommendations: "In a resolution on alternative to imprisonment the congress recommended that member state examine their legislation with a view towards removing legal obstacles to 
utilizing. alternative to imprisonment in appropriate cases in countries where such obstacles exist and encouraged wider community participation in the implementation of alternative to improvement and activities aimed at the rehabilitation of offenders."

Criminal deprivation of liberty in the form of prisons and confinement is the type of sanction most often imposed by judges in the criminal justice system in Indonesia. It can be seen from various court decisions in Indonesia that almost $98 \%$ impose imprisonment or confinement on convicts regardless of the type of crime or the seriousness of the crime committed by the perpetrators of the crime. The crime of deprivation in the form of imprisonment and confinement is considered to be very effective in preventing and overcoming crimes that occur in the community. Criminal sanctions emphasize the element of retaliation (raiding), which is suffering that intentionally imposed on an offender. In contrast, non-custodial sanctions originate from the basic idea of community protection and guidance or treatment of the maker. Or as JE Jonkers said, that criminal penalties emphasize criminal which applied for crimes committed, while non-custodial sanctions have social objectives.

Along with its development to improve the implementation of imprisonment is the existence of Minimum Standards Rules (SMR) which were initially designed by The International Penal and Penitentiary Commission (IPPC) in 1933. After the UN secretariat corrected the IPPC text, the SMR was finally approved by the UN congress the first concerning crime prevention and the promotion of lawlessness in 1955 in Geneva. Furthermore, the SMR approved by the UN Economic and Social Council in its resolution No. $633 \mathrm{C}$ (XXIV) dated July 31, 1957. Closely related to the acceptance of this SMR, the Second United Nations Congress on the prevention of crime and the promotion of lawbreakers in 1960 in London has issued recommendations to limit or reduce the widespread use of short prison sentences. Thus the need to develop local, national, regional and international strategies in the field of fostering perpetrators of crime and also alternative imprisonment can be an effective means for promoting perpetrators of crime and profits for the community.

Seeing from the many weaknesses and such broad negative impacts on imprisonment, various alternatives to the deprivation of liberty sought. According to the United Nations, the Minimum Rules for Non-Custodial Measure (The Tokyo Rules) establishes a set of fundamental principles for developing non-custodial measures and also develops minimum guarantees for people subject to alternative prison measures. These Minimum Rules intended to increase community involvement and greater participation, particularly in fostering perpetrators of crime, and increasing the sense of responsibility of perpetrators of crimes against the community. Non-custodial sanctions accommodated in positive law in Indonesia. Types of alternative punishments for deprivation of liberty in Indonesia's positive law that have been regulated positive Indonesian law are:

\subsubsection{Principal Crimes}

1. Conditional Crimes

The conditional criminal practice often referred to as a criminal trial, is a system $/$ model of illegal imprisonment by a judge whose implementation is unclear in certain conditions. It means that the criminal sentence imposed by the judge is not necessary to be carried out on the convict as long as the specified conditions are deemed not violating the convicted person. The benefit of conditional criminal offence is to fix criminals without having to put them in prison.

2. Criminal Fines

Criminal fines are other types of violations either as alternative confinement or as a standalone. Likewise, with different kinds of minor or culpa crimes, criminal penalties are 
often threatened as an alternative to imprisonment. Crimes are rarely punished with fines either as an alternative or not.

3. Parole

A stipulation of conditional release can be given by the Minister of Justice Article 15 paragraph 1 of the Criminal Code if the convicted person has served the third sentence or at least nine months (Article 15 paragraph 1 of the Criminal Code). The length of the intended criminal offence does not include the length of the temporary detention period. Means that the length of Supreme Court temporary detention not counted determining two-thirds or nine months even though in a judge's decision, it always stipulated that the sentence imposed is cut with a period of imprisonment.

4. Environmental Compensation and Recovery

The compensation sanction is a breakthrough in Law Number 32 of 2009, which previously in Act Number 23 of 1997 concerning Environmental Crimes recognizes that there are sanctions in the form of disciplinary action that can be imposed perpetrators of Criminal Acts The environment regulated in Article 47 determines:

a. Expropriation of profits derived from acts of speech or

b. Company closure (in whole or part); or

c. Repair due to criminal acts, and or

d. Require performing an action outside its authority

e. Put the company under the maximum capacity of 3 years

5. Rehabilitation

Rehabilitation is a new sanction in Indonesian laws and regulations, and this can be seen Law Number 35 of 2009 concerning Narcotics Article 54 through Article 59. Article 56 Paragraph (1) and (2) Act Number 35 of 2009.

\subsubsection{Additional Crimes}

There are three types of other crimes according to Article 10 of the Criminal Code:

1. Revocation of Certain Rights;

2. Confiscation of Certain Goods;

3. Announcement of Judge's Decision;

Furthermore, in the context of the renewal of the Indonesian criminal law, especially in the restoration of the National RKUHP, non-custodial sanctions are also adopted in the National RKUHP as specified in Article 65 of the RKUHP, which determines that: Principal penalties consist of: imprisonment; criminal closure; criminal supervision; criminal fines; and social work crime. Shows that criminal control, criminal punishment, and illegal social work are one of the leading criminal types which certainly can be handed down by the judge to the perpetrators of criminal acts. Re-emphasizing the importance of applying non-custodial sanctions to perpetrators of crime is also strengthened/reinforced in the provisions of Article 70 of the Criminal Code, which stipulates that: by considering Article 54 and Article 55 of the Criminal Code relating to the Objectives and Guidelines for Criminal Acts, imprisonment may not as far as possible drop if found the following circumstances:

1. the defendant is a child;

2. the defendant is over 75 (seventy) years old;

3. the defendant is committing a crime for the first time;

4. the loss and suffering of the victim is not too high;

5. the defendant has paid compensation to the victim;

6. the defendant did not realize that the criminal activities carried out would cause a significant loss; 
7. the crime occurred because of powerful incitement from others;

8. Victims of a criminal act encourage or mobilize the occurrence of such crimes;

9. the offence is a result of a situation that is unlikely to be repeated;

10. the defendant's personality and behavior assured that he would not commit any other crime;

11. imprisonment will cause great suffering to the defendant or his family;

12. guidance outside the correctional institution is expected to succeed for the defendant;

13. the conviction of lighter crimes will not reduce the severe nature of the criminal offence committed by the defendant;

14. Crimes occur among families; and

15. Crimes arise due to negligence.

Based on this description, it can see that it is essential in applying non-custodial sanctions by looking at some of the considerations contained in the perpetrator, in the victim and looking at the level of loss resulting from the crime and its impact on the community then the application of non-custodial sanctions is very likely to be carried out as a remedy for defendants, victims and the public. Is also as an embodiment of restorative justice by carrying out the settlement of cases/criminal acts by involving perpetrators, victims, perpetrators/victims' families to seek a fair solution by emphasizing restoration back to its original state and not retaliation.

The application of non-custodial sanctions, as described above, can be carried out at the adjudication and post-adjudication stages, which indeed are guided by several provisions that govern them. But at least ideally/the strategic step of applying non-custodial sanctions can be done at an early stage or at the pre-adjudication stage especially at the police level as the main gateway in the criminal justice system to suppress the number/stacking of cases at the next level. In connection with the above, if non-custodial sanctions applied at that stage, it can at least assist the process of resolving criminal cases so that they do not reach the prosecution or trial process. With the application of non-custodial sanctions, at least the accumulation of instances, especially at the policy level can be reduced at least each year. And if this sanction is applied the initial stage, it is likely that at the final stage (after the conviction) it can avoid overcapacity in correctional institutions.

The application of non-custodial sanctions in the pre-trial stage against perpetrators of criminal acts (by releasing perpetrators of crimes which of course with various considerations) requires a high level of professionalism from the police and prosecutors not to cause feelings of mutual suspicion between the two agencies. Likewise, at a later stage in the trial/court and correctional institutions. Where in both scenes, it is also possible for forgiveness by the judge. Furthermore, in the case of the application of non-custodial sanctions at each stage requires the role of supervisor and observer judges in the Criminal Procedure Code (KUHAP) and commissary judges in the Draft Criminal Procedure Code (RKUHAP) to the maximum in the context of the realization of restorative justice. In terms of criteria/measures against criminal offences (for example, minor crimes), the prosecutor may impose appropriate non-custodial sanctions for the offender.

In the adjudication stage, based on the criteria of criminal acts, the judge can also impose non-custodial sanctions that are appropriate for the perpetrators with various forms/variations which in their development have been accommodated in positive law in Indonesia and enforcing the law. Its use (for example, those contained in the Criminal Code, SPPA Law, Narcotics Law, Penitentiary Act, RKUHP, or other laws), such as conditional criminal, fines, criminal warning, criminal with conditions (such as; guidance outside the institution, community service, supervision) as well as job training and maintenance at rehabilitation 
centers. Or the possibility of a judge can apply an apology to the perpetrators of a criminal offence. In addition, in the post-adjudication stage, leave, remission, conditional release and forgiveness have at least used by authorized officials, only in its application can be further improved by adding unique criteria for inmates who are eligible to be given non-custodial sanctions or even accelerate the submission process, so that overcapacity can be quickly dealt with and ultimately fostering prisoners can succeed optimally, and the objectives of the criminal justice system both short-term, medium-term and long-term goals be realized.

\section{Conclusion and Recommendation}

The philosophical foundation of establishing non-custodial sanctions policies in the Criminal Code Bill is to respect and uphold human rights, and to create a balance based on religious, moral values of God, humanity, nationality, society, and social justice for all Indonesian people. Also, the establishment of a non-custodial sanction policy in the Criminal Code Bill is aimed at realizing a restorative justice for perpetrators of criminal acts. The imposition of non-custodial sanctions for offenders guided by the provisions of Article 71 of the Criminal Code Bill. The application of non-custodial sanctions also based on several considerations contained in the perpetrators, in the victim and looking at the level of loss resulting from the crime and its impact the community, so the application of non-custodial sanctions is very likely to do as a remedy for accused, victim the community. Is also certainly as an embodiment of restorative justice by carrying out Resettlement of cases/criminal acts by involving perpetrators, victims, perpetrators/victims' families to seek a fair settlement by emphasizing restoration back to its original state and not retaliation.

Based on the results and discussion above, it recommended that the Criminal Code Bill be immediately passed into law, so that non-custodial sanctions can be applied order to reduce the use of imprisonment and reduce over-load in Corrections. Furthermore, non-custodial sanctions should be prioritized by law enforcement in handling criminal cases, in order to bring about restorative justice for perpetrators of criminal acts.

\section{References}

[1] Abdussalam, H.R., dan Adri Desasfuryanto.(2012).Sistem Peradilan Pidana. Jakarta: PTIK.

[2] Achjani Zulfa, Eva.(2011).Pergeseran Paradigma Pemidanaan. Bandung: Lubuk Agung.

[3] Achjani Zulfa, Eva.(2006). Pergeseran Paradigma Pemidanaan di Indonesia.Jurnal Hukum dan Pembangunan, Vol. 3 (36), p. 393.

[4] Atmasasmita, Romli.(2010).Sistem Peradilan Pidana Kontemporer. Jakarta: Kencana.

[5] Dijk, Jan J.M, Van.(1997).Introducing Victimology, the 9th International Symposium Of The World Society Of Victimology. Amsterdam.

[6] Effendy, Marwan. (2012). Diskresi, Penemuan Hukum, Korporasi \& Tax Amnesty Dalam Penegakan Hukum. Jakarta.

[7] Fajar, Mukti, dan Yulianto Achmad, Dualisme Penelitian Hukum Normatif \& Empiris.

[8] Hotmaulana Hutauruk, Rufinus.(2013).Penanggulangan Kejahatan Korporasi Melalui Pendekatan Restoratif: Suatu Terobosan Hukum. Jakarta: Sinar Grafika.

[9] Ittichaisaree.(2001). International Criminal Law.Oxford: Oxford University Press.

[10] Lamintang, P.A.F.(1997).Dasar-Dasar Hukum Pidana Indonesia. Bandung: Citra Adtya Bakti.

[11] Mackenzie, Geraldine and Nigel Stobbs.(2010).Principles of Sentencing, 71 John St, Leichardt, Australia: The Federation Press.

[12] Marlina.(2009).Peradilan Pidana Anak di Indonesia: Pengembangan Konsep Diversi dan Restorative Justice. Bandung: Refika Aditama.

[13] Muladi.(1995).Kapita Selekta Sistem Peradilan Pidana. Semarang: Undip. 
[14] Muladi.(2002).Hak Asasi Manusia, Politik Dan Sistem Peradilan Pidana. Semarang: Badan Penerbit Universitas Diponegoro.

[15] Nawawi Arief, Barda.(2008).Bunga Rampai Kebijakan Hukum Pidana (Perkembangan Penyusunan Konsep KUHP Baru).Jakarta: Kencana.

[16] Nawawi Arief, Barda S. H. (2018). Masalah penegakan hukum dan kebijakan hukum pidana dalam penanggulangan kejahatan. Prenada Media.

[17] Sudarto.(1983).Hukum Pidana dan Perkembangan Masyarakat.Bandung: Sinar Baru.

[18] Smit, D. V. Z.(2007).Handbook of Basic Principles and Promising Practices on Alternatives to Imprisonment. New York.

[19] Walgrave, Lode.(2003).Repositioning Restorative Justice. Oregon: Willan Publihsing.

[20] Online. (2018). Sumber dari internet tentang Alternatives to Imprisonment; Is the prison sentence always the solution.Downloaded on 23 November 2019 dari http:// www.penalreform.org/resource/ ?pri priority=32, (16.30). 